\title{
PENGUNGKAPAN TANGGUNG JAWAB SOSIAL PERUSAHAAN DALAM PENDEKATAN HUMANIS DAN EMANSIPATORIS PADA PT. BANK MUAMALAT DI KOTA PALOPO
}

\author{
FITRIA ABDULLAH, MUH, AMIR ANAS, SAHARUDDIN
}

\begin{abstract}
ABSTRAK
Penelitian ini bertujuan mengetahui indikator humanis dan emansipatoris dalam pengungkapan tanggung jawab sosial yang di terapkan oleh PT. Bank Muamalat Capem. Palopo.

Data dianalisis dengan menggunakan metode indeks pengungkapan tanggung jawab sosial perusahaan dari data yang di peroleh.

Hasil penelitian menunjukkan bahwa dalam pengungkapan tanggung jawab sosial perusahaan terdapat indikator humanis dan emansipatoris dalam penerapan tanggung jawab sosial perusahaan pada PT. Bank Muamalat Capem. Palopo.

Pengungkapan tanggung jawab sosial perusahaan PT. Bank Muamalat Capem. Palopo yang tergolong dalam pendekatan emansipatoris dalam penerapannya antara lain pendidikan dan pelatihan (dukungan penelitian, magang dan pelatihan. Dukungan dalam kegiatan MTQ, pelayanan pada lembaga yang mengajukan proposal, majelis taklim untuk perkembangan dakwah dan dukungan tablik akbar, serta zakat). Kesejahteraan karyawan melalui pemberdayaan karyawan dan keluarganya dan kepuasan nasabah dengan informasi dan sosialisasi-sosialisasi produk terbaru serta pelayanan yang baik.
\end{abstract}

Kata Kunci : Pengungkapan Tanggung Jawab Sosial, Humanis, Emansipatoris. 


\section{Pendahuluan}

\section{Latar Belakang}

Seperti yang kita ketahui bersama bahwa dalam suatu organisasi/perusahaan memiliki tujuan utama yaitu memaksimalkan laba untuk kepentingan pemilik perusahaan tanpa harus terlalu mementingkan kepentingan social, dalam hal ini, Corporate Sosial Responsibility (CSR). Padahal it bertentangan dengan akuntansi syariah, di mana akuntansi syariah memiliki tujuan yang di kemukakan oleh Triyuwono (2006:320) adalah terciptanya peradaban bisnis dengan wawasan humanis, emansipatoris, transcendental, dan teleological. Dengan akuntansi syariah, realitas social yang di bangun mengandung nilai tauhid dan ketundukan kepada ketentuan allah swt.

Dari kutipan diatas dapat di ungkapkan bahwa akuntansi syariah lebih mengarah kepada sifat yang manusiawi yang tercipta berdasarkan budaya itu sendiri, mampu melakukan perubahan-perubahan bernilai syariah, tidak hanya berfokus pada materi tetapi juga pada mental dan spiritual, serta dapat bertanggung jawab kepada sang pencipta allah SWT, sesama manusia, dan lingkungan.

Sejauh ini yang menjadi kendala antara perusahaan dengan masyarakat umumnya dan yang berkepentingan langsung pada perusahaan tersebut adalah CSR. Timbul pertanyaan "apakah CSR hanya dapat berupa amal, humas atau yang berhubungan langsung dengan alam, bagaimana jika perusahaan tersebut berupa suatu bank dan berbasis syariah, dimana latak CSR-nya?".

CSR tidak hanya dilihat dan dilaksanakan melalui usaha amal saja, namun itu hanya sebagian kecilnya. Informasi pun merupakan suatu tanggung jawab social. Tanpa informasi yang baik stakeholders dan entitas lainnya enggan bekerjasama dengan perusahaan karena kurang perhatiannya terhadap CSR.

Telah kita ketahui bersama bahwa Bank Muamalat yang berada di kota palopo, pro. Sul-sel adalah bank yang berbasis syariah. Dengan dasar tersebut diatas peneliti mengangkat indicator-indikator apa saja yang terdapat di dalam nilai humanis dan emansipatoris yang digunakan untuk penerapan tanggung jawab social pada Bank Muamalat di kota palopo. Masalah penelitian ini adalah apakah terdapat indicator-indikator humanis dan emansipatoris dalam pengungkapan tanggung jawab social yang diterapkan oleh PT. Bank Muamalat di kota palopo?.

Tujuan pnelitian ini adalah untuk mengetahui indicator-indikator humanis dan emansipatoris dalam pengungkapan tanggung jawab social yang di terapkan oleh PT. bank muamalat di kota palopo. 


\section{Metode Penelitian}

\section{Tempat Penelitian}

Dalam melakukan kegiatan penelitian ini, penulis akan memilih objek penelitian pada suatu Bank yang berbasis akuntansi syariah dan berada di kota palopo. Pro.Sulawesi Selatan. Nama bank tersebut adalah bank muamalat, cabang kota palopo.

\section{Jenis Dan Sumber Data}

1. Data primer merupakan data yang diperoleh dari hasil observasi dan wawancara langsung dengan pihak PT. Bank Muamalat Capem. Palopo yang berhubungan dengan tanggung jawab social perusahaan.

2. Data sekunder adalah data tertulis yang diperoleh dari bank muamalat Indonesia yang berupa laporan tahunan dan data tertulis yang diperoleh dari PT. bank muamalat capem, palopo.

\section{Metode Pengumpulan Data}

Metode pengumpulan data yang digunakan dalam penelitian ini adalah: (a) Field research (penelitian lapangan) yaitu dengan mengambil data mengenai kegiatan CSR yang di programkan oleh bank muamalat di kota palopo. (b) Di samping itu, metode pengumpulan data dan informasi-informasi terkait yang digunakan penulis dalam penelitian ini adalah penelitian kepustakaan ( library research) yaitu melalui bukubuku referensi, jurnal, karya ilmiah, teori-teori website dan melalui situs-situs yang terkait dengan penelitian ini

Metode Analisis Data

Data yang telah dikumpulkan dianalisis dengan menggunakann alat analisis yakni sembiring (2005) dalam Rahmawati (2010): analisis variabel yaitu pengungkapan tanggung jawab sosial perusahaan dengan menghitung indekks pengungkapan yang terpenuhi :

$\mathrm{IP}=\mathrm{n} / \mathrm{k}$

Keterangan :

IP : indeks pengungkapan,

$\mathrm{n}$ : jumlah butir pengungkapan yang terpenuhi,

$\mathrm{k}$ : jumlah semua butir pengungkapan yang terpenuhi.

Batasan indeks pengungkapan 0,5 keatas atau 50\% keatas merupakan indeks yang menunjukkan bahwa penerapan CSR yang bagus. 


\section{Hasil Penelitian Dan Pembahasan}

\section{Hasil Penelitian}

Dari data yang di peroleh dari PT. Bank Muamalat tentang tanggung jawab sosial perusahaan merupakan bagian-bagian yang tidak terpisahkan dari kegiatan perusahaan dalam menjalankan operasionalnya dan pencapaian tujuan. Namun apakah dalam mengimplementasikan tanggung jawab sosial perusahaan oleh PT. Bank Muamalat Capem. Palopo terdapat indicator humanis dan emensipatoris terhadap masyakarakat sekitar, karyawan dan nasabah.

1. Data pengungkapan program tanggung jawab sosial perusahaan PT. Bank Muamalat Indonesia periode 2008-2010

Mengingat masih sedikitnya perusahaan di Indonesia yang mengungkapkan tanggung jawab sosial perusahaan dalam bentuk sustainability reporting, maka penelitian ini pun terbatas hanya pada data-data yang terdapat dalam laporan tahunan perusahaan.

2. Data pengungkapan tanggung jawab sosial perusahaan PT. Bank Muamalat Capem. Palopo periode 2008-2010

Data pengungkapan tanggung jawab sosial perusahaan PT. Bank Muamalat Capem. Palopo periode 2008-2010 ini merupakan hasil kuesioner penulis yang berdasarkan pada annual report Bank Muamalat utama dan selebihnya merupakan hasil wawancara penulis dengan narasumber bapak Hadi Santoso, selaku relationship manajer bank muamalat palopo.

Dari data tersebut terdapat indikator humanis dan emansipatoris dalam penerapan CSR di PT. bank muamalat capem. Palopo periode 2008-2010 meskipun tidak semua program terlaksana seperti halnya di bank muamalat utama. Bentuk CSR dalam konteks humanis yang diterapkan di palopo yaitu dalam program sosial dan kemanusiaan yang dalam bentuk kegiatannya adalah SBL berbagi cahaya ramadhan; dilakukan dalam bentuk santunan untuk sahur, berbuka, dan lebaran (SBL), penyaluran hewan Qurban kepada keluarga miskin dan anak yatim, serta program Go-Green penanaman pohon dan pengadaan tempat sampah pada periode 2008 .

Untuk tahun 2009 masih sama dengan program tahun 2008 yang berupa santunan SBL, penyaluran hewan Qurban. Namun di tahun ini ada penambahan kegiatan yaitu ATM berupa bantuan kepada korban tanah longsor di kec. Battang, sedangkan tahun 2010 hanya melaksanakan kegiatan SBL dan penyaluran hewan Qurban.

Sementara itu bentuk CSR dalam bentuk emansipatoris yang diterapkan di palopo yaitu program pendidikan dan pelatihan, pelaksanaan ZIS, dan kesejahteraan karyawan dan kepuasan nasabah. Kesejahteraan karyawan melalui pemberdayaan karyawan dan keluarganya, bersifat adil terhadap semua karyawan dalam hal waktu, tenaga, mengeluarkan pendapat, inovasi gaji/bonus karyawan, ras, jender, serta informasi, memberikan kesempatan belajar untuk semua karyawan, pengembangan 
diri melalui training dan penelitian. Kepuasan nasabah dengan informasi dan sosialisasi-sosialisasi produk terbaru.

Untuk mengetahui berapa persen pengungkapan CSR dengan pendekataan humanis dan emansipatoris, maka penulis menggunakan metode analisis dengan menghitung indeks pengungkapan yang terpenuhi sesuia dengan metode pengungkapan yang di gunakan oleh Sembiring (2005) dan Rahmawati (2010) adalah:

$$
\begin{aligned}
& \begin{array}{l}
\mathrm{IP}=\mathrm{n} / \mathrm{k} \\
\text { Keterangan : IP : indeks pengungkapan } \\
\mathrm{n}: \text { jumlah butir pengungkapan yang }
\end{array} \\
& \text { diharapkan } \\
& \text { yang terpenuhi. }
\end{aligned}
$$

\section{Pembahasan}

Indikator dari kegiatan tanggung jawab sosial perusahaan ( Corporate Social Responsibility) dalam konteks humanis ini dapat di contohkan dalam kegiatan sosial (tolong-menolong), peduli lingkungan/alamm, kesehatan, dan ekonomi.

Corporate social responsibility dalam kegiatan sosial, peduli lingkungan/alam, dan ekonomi sosial di lkaukuan dengan adanya factor dehumanisasi yang terjadi di tengah-tengah masyarakat sekitar perusahaan saat ini. Dimana, dehumanisasi merupakan efisiensi dan mekanisasi yang menciptakan persoalan sosial dikalangan masyarakat akibat dari perampingan perusahaan menimbulkan PHK dan pengangguran, ekspansi daan eksploitas industry melahirkan ketimpangan sosial, polusi, dan kerusakan lingkungan yang hebat (Suharto, 2007) dalam web 2011.

Sedangkan, indikator dari kegiatan tanggung jawab sosial perusahaan ( corporate social responsibility) dalam konteks emansipatoris dapat diterapkan pada peningkatan pendidikan, pemberdayaan karyawan dan keluarganya, informasi, kesejahteraan dan kepuasan nasabah zis dan pemberdayaan wakaf.

Dalam penelitian ini penulis mendapatkan hasil bahwa dalam pengungkapan tanggung jawab sosial perusahaan pada PT. Bank muamalat capem. Palopo terdapat indikator humanis didalam penerapannya (hipotesis diterima) meskipun jauh lebih dibawah dibandingkan dengan muamalat pusat yaitu rata-rata $16,6 \%$ indeks pengungkapan dalam tiga tahun. Indikator yang terpenuhi selama tiga tahun meliputi sosial dan kemanusiaan ( santunan SBL, bantuan bencana alam) peduli lingkungan, dan penyaluran hewan qurban.

Selanjutnya yaitu pengungkapan tanggung jawab sosial perusahaan pada PT. Bank muamalat capem. Palopo terdapat indikator emansipatoris didalamnya penerapannya (hipotesis diterima). Indikator ini lebih banyak terlaksana 
dibandingkan dengan humanis mencapai rata-rata $61 \%$ indeks pengungkapan dalam tiga tahun, antara lain pendidikan dan pelatihan (dukungan penelitian, magang dan pelatihan. Dukungan dalam kegiatan MTQ, pelayanan pada lembaga yang mengajukan proposal, majelis taklimuntuk perkembangan dakwah dan dukungan tablik akbar, serta zakat).

Kesejahteraan karyawan melalui pemberdayaan karyawan dan keluarganya, bersifat adil terhadap semua karyawan dalam hal waktu, tenaga, mengeluarkan pendapat, inovasi, gaji/bonus karyawan, ras, jender, serta informasi, memberikan kesempatan belajar untuk semua karyawan, pengembangan diri melalui training dan penelitian. Kepuasan nasabah dengan informasi dan sosialisasi-sosialisasi produk terbaru serta pelayanan terbaik.

Tingkat pengungkapan CSR dalam konsep humanis lebih rendah disbanding dengan tingkat pengungkap CSR dalam konsep emansipatoris dalam setiap tahunnya selama tiga tahun terakhir. Hal ini di akibatkan karena belum berjalannya programprogram ini seperti yang telah berjalan dipusat dan sebagian dari program tersebut adalah wewenang pusat dalam menentukan apakah capem. Bisa ikut dalam menerapkan program CSR tersebut.

\section{Penutup}

Kesimpulan penelitian ini adalah: (a) Pengungkapan tanggung jawab sosial perusahaan dengan menggunakan indeks pengungkapan menunjukkan bahwa terdapat indikator humanis dan emansipatoris dalam penerapan tanggung jawab sosial perusahaan pada PT. Bank muamalat capem. Palopo, (b) Peran tanggung jawab sosial perusahaan merupakan bagian yang tidak terpisahkan dari tujuan usaha bank muamalat untuk mewujudkan tatanan masyarakat yang adil dan makmur sejalan dengan prinsip dasar ekonomi syariah. Adapun saran dari penelitian ini adalah: (a) Pada pengungkapan tanggung jawab sosial perusahaan tidak hanya berupa materi dan usaha amal saja namun informasi juga menunjang dalam pengunkapan CSR pada suatu organisasi ketika pengungkapannya valid dan merupakan kebutuhan stakeholders. (b) Perusahaan harus meningkatkan perhatian kepada tanggung jawab sosial perusahaan secara sukarela baik dari segi pendekatan humanis maupun emansipatoris, (c) Peneliti selanjutnya meneliti lebih banyak lagi indikator dan pendeketan dalam penerapan tanggung jawab sosial perusahaan pada suatu organisasi. 


\section{Daftar Pustaka}

$\mathrm{Al}$-Qur`an dan terjemahannya, penerbit Cv. Dipenogoro, Bandung.

Abdurrahim ahim, rizal yaya, danang aji nugrah. 2007. Kesenjangan harapan antara nasabah dan manajemen terhadap penyampaian informasi keuangan dan non keuangan bank syariah, jurnal akuntansi dan investasi, fakultasi ekonomi UMY, Yogyakarta.

Mulawarman aji dedi. 2006. Menyibak akuntansi syariah: rekonstruksi teknologi akuntansi syariah dari wacana ke aksi, kreasi wacana, yagyakarta.

Rahmawati. 2010. Pengaruh profitabilitas, persentase kepemilikan, komite audit dan budaya terhadap pengungkapan tanggung jawab sosial pada laporan keuangan tahunan perusahaan tambang di Indonesia. Tesis. Program pasca sarjana universitas hasanuddin.

Rismawati. 2006. No business interruption : tanggung jawab sosial dan akuntansi pertanggungjawaban sosial dalam perspektif budaya luwu (studi pada PT. INCO Sorowako). Tesis. Program pasca sarjana Univ. brawijaya malang.

Triyuwono iwan. 2006. Akuntansi syariah: perspektif, metodologi, dan teori 2 ed. PT. Raja Grafindo Persada, Jakarta.

Situs internet/website:

Anonym, competitiveness at the FRONTIER, Juni 2008. Web@ Google 2010. 